\title{
ADULT EDUCATION AS A PANACEA FOR HIV/AIDS STIGMATIZATION IN NIGERIA
}

\author{
MUHAMMAD SHEHU HUSSAIN
}

\begin{abstract}
The main purpose of adult education is basically to help improve the status of people especially the disadiamaged to enable them to participate actively in the development of their respective commmities and societs in general. Stigma is a sign of social unacceptability or shame or disgrace atrached to something. the essence is for people living with HIV/AIDs to live free from discrimination and inclined to declare and acknowledge their health status. It is against this background that the paper suggested that adult education programmes like literacy education, health education amongst others are capable for providing a solution in order to ameliorate the scourge of stigma from people living with HIV/AIDs.
\end{abstract}

\section{Introduction}

Adult education began with the creation of man, it was imperative for those forebears in Africa to provide education for the adult population so as to ensure the survival and the development of skills, integration, group cohesion, societal values and acceptable attitudes. Adult education is embedded in the political, social, cultural and economic processes of the society. This suggests that the nature of adult education policies. programmes and practices reflects the interest and values of different social groups and distribution of power and influence in the society (Walters \& Watters, 2002)

Presently man is seriously being challenged by constant changes in technology and rapid increases in new knowledge. Apart from these, the unhealthy fears and misunderstanding of various aspects of death and dying challenges man into studying the end of life (Nzeneri, 2005)

In this paper the term adult education is used in an inclusive way to refer to all educational provisions for adults. its social purposes can be thought as:

- Education that enhances the strategies that enables women and men to survive the harsh conditions in which they live. Example of this includes literacy, primary. health care and some home craft skills.

- $\quad$ Education and training geared to developing skills for people in the formal and Non-Formal sectors would describe education for economic purposes.

- Cultural and political education which aims to encourage the women and men to participate actively in society through network of cultural organizations, social movements, political parties and trade unions.

Okedara (1996) defined adult education as "all educational activities arranged for adults without any legal compulsion".

UNESCO (1994) considers adult education to cover all organized educational activities provided for people who are not in regular schools or university system and who ale generally 
eighteen or older. UNESCO under scores the aspect of age when it refers to adult learners who are defined on the basis of maturity and responsibility.

\section{Traditional Adult Education}

According to Fafunwa (2004)" the aim of traditional African education is multilateral and the end objective is to produce an individual who is honest. respectable, skilled, and cooperative and conform to the social order of the day". Omolewa (1985) noted that traditional education was done out -of- school essentially at home, the centre of character training and base for the introduction of vocational education, he further pointed out that "the emphasis in traditional society was on the integration of all aspects of education, formal, nonformal and informal"

Bockaries (1991) mentioned that: Prolonged formal aspects of indigenous education exist and these take place in organized groups in fixed and secluded places under guidance of acceptable instructors. It is important to note that. in the present teaching and learning process, the largest number of adult learners still operates in traditional adult education which still has merits of a strong code of conduct, cultural relevance based on the philosophy of learning by doing (apprenticeship) which starts from early childhood to grave.

Thus, it can be accepted that adult education consists of learning programmes which are meant for adult learners. This conception has its root from Anglo-American concepts of adult education which as rule, maintains that adult education embraces persons in age classes of over 18 years (OVRUP.1989) there is inherent weakness in limiting the age to over 18 years since the number of years of determining adulthood is not universal.

UNESCO (1972) states that adult education denotes adult education as:

The entire body of organized educational processes whatever the content. level and method whether formal or otherwise whether they prolong or replace initial education in schools, colleges and universities as well as in apprenticeship, whereby person regarded as adult by the society in which they belong, develop their abilities, enrich their knowledge, improve their technical or professional qualifications and bring about changes in their attitudes or behaviour in two fold perspectives of full personal development and participation in balanced and independent social, economic and cultural development.

\section{UNESCO (1994) considers adult education:}

"to cover all organized educational activities provided for people who are not in school and university system and who are generally fifteen or older". UNESCO underscores the aspect of age when it refers to adult learners who are defined on the basis of maturity and responsibility. In other words, the word adult is not considered in terms of only those who attained 18 or 21 years of age who voting rights. In the African context, an adult is one who is matured and has adult responsibility such as being married with children.

According to Afrik, (2000) the objectives of adult education programmes are generally taken as six 
folds:

- To develop policies. plans and strategies

- To train and retrain personnel

- To conduct action research

- To develop curricula and didactic materials

- To promote information flows

- $\quad$ To mobilize and sensitize public opinions

\section{Stigma and discrimination}

HIV/AIDS is a virus that is found in the body. Stigma is found in the thoughts of people and communities. when people believe that a particular illness or something a person has done or feels is shameful and brings disgrace on themselves, their family or despised and avoided by the community. Stigma is defined as a powerful and discrediting social label that radically changes the way the individuals view themselves and are viewed by others (Abdullahi, 2003).Stigma and discrimination are two major problems often faced by people living with HIV/AIDS in much of the developing countries including Nigeria. Stigma and discrimination shown to persons living with HIV/AIDS can worsen the spread and the impact of the HIV/AIDS endemic. Bartllet (2007) defined stigma as a deeply discrediting attribute that reduces a person to someone who is in some way tainted and can be denigrated. It is pervasive problem that affects health globally, threatening an individual's psychological and physical well-being. Due to the fear of discrimination. individuals living with HIV/AIDS may be less inclined to live freely. declaring and acknowledging their HIV status. In other words stigma is a sign of social unacceptability or shame or disgrace attached to something. Because of this stigma. individuals. families and whole community often discriminate against others in a way that causes great sufferings. Stigma also leads to resistance to counseling and testing thereby undermining successful HIV/AIDS management. Kalichman and Simbayi (2003) sees stigma as a construction of deviation from some ideals or expectations. For Herek and Capitanio (1999). stigma is an enduring attribute of an individual infected with HIV that is negatively valued by society and disadvantages of people living with HIV/AIDS. They views HIV -related stigma as prejudice. discounting. discrediting. discrimination directed at people perceived as having HIV/AIDS, and at individuals, groups and communities with which they are associated. People who are stigmatized are usually shameful and as a result are shunned. discredited, rejected or penalized.

\section{Adult Education programmes}

The following are some of the Adult education programmes:

- Literacy education: is traditionally associated with the teaching of reading, writing and numeracy skills at the most rudimentary level. It equips people to participate with judgement and understanding, in the administration of their own affairs, and with success in their economic, social, cultural. and political advancements. It fosters in them the spirit of community development.

- Health education: this is a form 
of extension programme that involves sensitizing the populace towards good health habits. It teaches people to appreciate the fact that good health is an attribute of happy life. Through health education people learn how important health is for real life happiness and permanent posterity.

- Distance education: involves the use of multi-media for educating a large group of people who may be dispersed in different places. The teachers and learners are spatially separated although occasional tutorials or teacherstudents contacts may be provided to complement selfinstructional materials.

- Remedial education: this is a form of adult and non-formal education which is generally designed to remedy an educational deficiency. It presupposes that the learners had earlier taken part in one type of educational programme but could not complete it due to certain unfavourable conditions. Remedial education therefore is designed to offer a second chance or opportunity to that particular adult learner to complete the level of education.

- Community development: this is a process of inculcating in the people the spirit of self-help, to develop responsible local leadership; to inculcate among members of a community a sense of citizenship and a spirit of civic consciousness and to introduce and strengthen democracy at the grassroots level.

- Environmental

education: involves inculcating good sanitation habits on the people. Through environmental education, people will be aware of the dangers posed by environmental pollution and degradation. It also develops in people the right skills and attitude towards the environment. The need for environmental education practices becomes a matter of importance so that people can escape the worst of their own uncertainties in an uncertain world.

- Women education: this is educational programmes specifically designed for women to make them play their roles in the society more productively. The goal of women education is the development of functional skills, literacy and numeracy skills, the development of occupational skills which will lead to increase in income and the development of critical consciousness and professional competencies so that women can initiate, create and manage social institutions and provide requisite services in their environment for their growth and development.

- Workers education: this a form of adult and non-formal education that provides workers with opportunities to acquire new skills relevant to day-to-day operations and also to renew obsolete and irrelevant skills that are no longer needed by the enterprise. 


\section{Capacity}

Is the combination of people, institutions, and practices to achieve results. to perform and provide a service (Yahaya. 2003).

\section{HIV/AIDS situation in Nigeria}

HIV/AIDs is today a house hold name. This is because of the devastating effects it has. on the national growth and development. The problem is no longer new, within the period of its existence available data reveals a steady increase in its prevalence. the first case of HIV/AIDS in Nigeria was noticed in 1984 (Abdullahi,2003). The rate at which the virus is spreading is fast and the effect cannot be over estimated. The psychological stigma due to prejudice and discrimination as well as stereotyping directed towards HIV/AIDS even worsen the situation thereby making counseling difficult.

The national HIV/syphilis sentinel survey conducted by Federal Ministry of Health in 2002 on pregnant women attending ante-natal clinics shows a national maiden prevalence of 5.8 percent for ages 15-49 years. The specific values ranged from $1 \%$ in lowest state to $15 \%$ in the highest state prevalence. The age specific prevalence rate was highest from the age group 2024 years at $6.5 \%$. In 2002, the ministry estimated the population of people with HIV positive as 3.47 million, 4.5 years decrease in life expectancy due to HIV and 1.4 million as projection of deaths due to AIDS as well 847,000 AIDS orphans were estimated (FMH. 2002)

The route of transmission had psychological and sociological effects.
The psychological and sociological effects of HIV are also remarkable from the point of view of the individual and the society, as well as from the ethical and political aspects. Socially HIV is associated with images and feelings of the guilt. sexually and death. The society associates homosexuals. bisexuals and users of intravenous drugs, prostitutes or often simply deviant or otherwise odd people with the discussion of taboos. Originally, AIDS was associated with the taboos of death and sexuality transmitted disease. Sexuality in itself is combined with shame and guilt, fear and death. Hence AIDS has to be punished of God to the patient for his/her sexual misconduct (Lindquist, 2002)

\section{Recommendations}

Education, however must encompass not only preventive education for out -of school youths, but must also include literacy training and non-formal methods for the education of adults and out-ofschool youths. A general adult education itself has a preventive impact, providing individuals with knowledge to make a healthy decision about their own lives:

- Health Education: the most elementary urge in man is to remain alive. Merely exist would mean that he is no higher than other organisms. To live signifies far more to a human being than merely to function biologically. Health Education as. a form of adult education teaches people to appreciate the fact that good health as an attribute of happy life, cannot be purchased from the shop or market. Health Education will provide information to bring about self 
and healthy behaviours. Film shows that will convey messages of stigma should be produced in order to enlighten the public on the dangers of stigma on the People Living with HIV/AIDS. The messages has to be clear on how people can be infected with the disease. The Health Education should take the message to the door steps of the people and discourage them on the stigma and its antecedents

Literacy Education: gives the opportunity for economic independence in addition to ensuring basic education for all, specific information about the spread and production of HIV/AIDS must be included in adult literacy and non-formal education programmes. Acquisition of literacy skills is critical so that individuals can communicate and understand current information about HIV/AIDS. Adult literacy and non-formal education programmes should incorporate the following strategies into their curricula.

- Integrating Reproductive Health and Sexual Education into Post literacy programme. Experts in Health care delivery should be given opportunity to come to the classes and present lectures on stigma and also shed more light on ways of infection. Also since the programme is meant for adults some periods should be dedicated for discussions on health promotion issues to be delivered by resource persons either on weekly or monthly to acquaint the participants on how best to avoid HIV/AIDS and discourage the people on stigma.

- Greater reliance on Education by Peers from and outside the programme-Community

members should be trained and encouraged to form discussion groups that will be meeting time to time discussing issues on HIV/AIDS and stigma amongst themselves, during the training, issues that relate to stigma will be thoroughly discussed and solutions proffered by the community members.

- Capacity building mechanisms: will incorporate training and empowerment of care givers who ensure the safety and well being of children. Extensive community sensitization should be adopted where every person can be reached on the health discussion.

- Community Education and Rehabilitation; should capitalize on the community resources inherent in Persons Living with HIV/AIDS. Community forums like the town hall meetings. naming ceremony. wedding ceremony, during Friday sermons amongst others should also be used as an avenue to discuss issues that concern stigma and other health issues like routine immunization and other killer diseases that are bedeviling the community and chart for way out.

- Establishing linkages with critical support services, especially in health areas. The adult education programmes should provide an avenue, where the health care providers caln be 
used in order to reach out to the public for health promotion activities and also to achieve Millennium Development Goals especially goal 4.5 and 6 .

\section{Conclusion}

Education is seen as a process of training and re-training and imparting in children. young people and adults in formal and non-formal settings. Hence. education is designed to give knowledge and develop skills. For those living with HIV/AIDS, stigma is one of the most insidious barriers affecting access to and provision of health services especially in places where services are lacking. Illiteracy, poverty and HIV/AIDS are the triad scourges ravaging people's life all the world and stigma often aggravates issues as it concerned those living with the scourge. Strengthening Adult Education capacity as a panacea for HIV/AIDs stigmatization in Nigerian society is highly desirable. This has been the emphasis of this paper. This implies that Adult Education should be better organized and enriched in its programmes in a way that enables the beneficiaries to attaint self -fulfillment, be socially useful, be empowered to participate fully in the nations democratic process and be economically more productive.

Findings have shown that people living with HIV/AIDS or perceived to have HIV are often discriminated, discounted and discredited, otherwise called stigmatization. Stigma removes power from the stigmatized persons, promoting differences or reducing the stigmatized groups or person's social status and self worth. A major cause of HIV/AIDS stigma includes insufficient knowledge. misconception, preformed information, fears and prejudice commonly referred to as stereotype. HIV stereotyping though causes stigmatization, it is however a preformed belief, information or negative perception people have in relation to the causes and spread of HIV/AIDS

\section{References}

Abdullahi, M. I. (2003). Guidance and counseling strategies for the prevention and Management of HIV /AIDS prevalence in schools in Saye. S.M. (ed), main Issues in guidance and counseling for tertiary institutions, 1 (136 - 147).

Afrik, T. (1993). Reflection on two National case studies: Keys for the launching of mass Literacy campaign (original in French).

Bartlett. J. K. (2007). Acquired immune deficiency syndrome: microsoft student DVD. redmond. W.A. Microsoft Corporation

Bockaries, S. A. (1991). School Community integration: A microsm of the process of Non-Formal education. London. Pergamond publishers

Fafunwa, A. B. (1974). History of Education in Nigeria. London: George Allen and Unwin.

Federal Ministry of Health (2002). Technical report on the 2001 national HIV/syphilis Sentinel survey among pregnant women attending ante-natal clinics in Nigeria Available at http:// www.ernwacatorg.retrieved 


\section{$26 / 10 / 2012$}

Herek, G. M. (1999). AIDS stigma and knowledge about HIV/AIDS transmission in the United States. University of California. Davis unpublished manuscript

Kalichman. S. C. \& Simbayi. L. C. (2003). HIV testing attitudes. AIDS stigma and voluntary counseling and testing in a black township in Cape Town. South Africa. Seriual Transmitted Infections, 76 (6): 125 $-142$.

Lindquist, M. (2002). HIV/AIDS as an ethical issue. in Aaltonen, $U$.; Arsalo, A. \& Sinkkonen, M. (eds). being positive: perspectives on HIV/AIDS in the EU's Northern dimension and Finland's neighbouring areas. Helsinki Finland.

Nzeneri, I. S. (2005). The concept and scope of adult and non-formal education in Okediran. A (ed) Adult and Non-Formal education in Nigeria emerging issues. NNCAE annual conference Nov 27.

Okedara, J. T. (1996). Regional and national organization: Africa. Anglophone in Tuijnman, A.C. (ed) international encyclopedia of adult education and training, second edition, London: Pergamorg.

Omolewa, M.A. (1981). Adult education practice in Nigeria. Ibadan: Evans brothers publisher.

UNESCO (1994). Education for All: status and trends. Paris: UNESCO.
UNESCO (1972). Final report; third international conference on adult education, Paris: UNESCO

Walters, S. \& Watters, K. (2000). From adult education to life long learning in southern Africa over the last twenty years in Indabawa and others (ed) (2000): the state of adult education in Africa. Namibia: John Meinert Printing.

Yahaya. A. D. (2002). Strengthening civil service Capacity as a panacea for civil service reforms. A text of a paper presented at a Civil service day in merit house Abuja, $23^{\text {rd }}$ July. 